\title{
Die rol van die Saamwerk-Unie in die beslaggewing van Afrikaanse taaleksamens in Natal, 1917-1928
}

\author{
P.J.J. Prinsloo
}

Departement Geskiedenis

Potehefstroomse Universiteit vir CHO

Vaaldriehoekkampus

VANDERBIJLPARK

\begin{abstract}
The role of the Co-operative Union in establishing Afrikaans language examinations in Natal, 1917-1928
\end{abstract}

This article deals with the role of Afrikaner Nationalists who had striven to develop the self-assertiveness of their compatriots by means of promoting Afrikaans. Their attempt was aimed at obtaining an equal position to the deeply-rooted British tradition in Natal.

The Co-operative Union ("Saamwerk-Unie") consequently had taken up position in the midst of the language problems. The Union made a deliberate attempt at promoting the development of Afrikaans by means of establishing the first language examinations in Afrikaans.

This examination system evoked greater interest with every passing year and resulted in a clash between the Co-operative Union and the South African Language Union. The Language Union, with its Dutch language examinations, was the embodiment of the Dutch influence, while the Co-operative Union promoted Afrikaans at grass roots level. A compromise between the two organisations thus had to be made. A joint Examination Commission was therefore established in 1928. Consequently, the new cultural pattern which had been launched by the Co-operative Union was acknowledged in the ranks of the Afrikaner. 


\section{Inleiding}

In die huidige tydsgewrig van herskikking in Suid-Afrika - 'n tyd waarin onder andere belangrike besluite oor taal- en kulturele regte geneem word (Beeld, 1993-05-29), is dit noodwendig dat 'n saak soos die uitbouing van Afrikaans opnuut in die brandpunt staan (Pienaar, 1946:340; Adam \& Moodley, 1993:140-146). Hierdie situasie het tot gevolg dat die eeue lange taalstryd rondom Afrikaans weer in volle gang is (Steyn, 1987:1; Zietsman, 1992:1, 200, 201).

Die doel van hierdie artikel is om ' $n$ historiese visie oor die vestiging van Afrikaans as skryftaal in Natal te bied. Die sentrale tema van die artikel is 'n ambisieuse taaleksamenstelsel wat deur die Natalse Saamwerk-Unie vir Natalse Afrikaanssprekendes geïnisieer is. In die tydperk wat ter sprake is, naamlik 1917-1928, het die instelling, beslaggewing en erkenning van die taaleksamenstelsel plaasgevind.

Ten einde die doelwit van 'n historiese oorsig te bereik word die totstandkoming van die Afrikaanse taaleksamens in Natal in samehang met die ontwikkelingswerk van die Suid-Afrikaanse Taalbond beskryf. Die rede hiervoor is dat die taaleksamenstelsel uit die staanspoor belangstelling gaande gemaak en die Saamwerk-Unie se werksaamhede landwyd bekendgestel het (INEG, lêer 1/4/2/1/1, 1917-05-24, 25).

Die byderwetse besluit van die Saamwerk-Unie in 1917 het die Taalbond onkant betrap omdat die Taalbond se taaleksamens slegs Hollands bevorder het. Hierdie artikel toon dat daar bykans 'n dekade verloop het voordat die Saamwerk-Unie en die Suid-Afrikaanse Taalbond oor hierdie saak tot ' $n$ vergelyk gekom het. Die onderhandeling tussen die SaamwerkUnie en die Suid-Afrikaanse Taalbond werp nie net lig op 'n provinsiale taalstryd nie, maar verduidelik ook die verskille wat in die geledere van die twee organisasies voorgekom het (Prinsloo, 1987:271-280).

Heelwat geskrifte het oor die onderwerp verskyn. G. Besselaar was die eerste persoon wat gedurende 1917 die ontwikkeling op taal- en kultuurgebied in Natal geëvalueer het (De Afrikaner, 1917-06-05). E.G. Jansen het as eerste voorsitter van die Saamwerk-Unie gedurende 1941 'n artikel oor die organisasie geskryf (Jansen, 1941:15). P.C. Schoonees het eweneens 'n kort artikel oor die Saamwerk-Unie gelewer (INEG, lêer $4 / 1 / 1 / 1$, s.j.).

$226 \quad$ ISSN 0258-2279

Literator 16 (2) Aug. 1995:225-245 
Gedurende die dertigerjare het twee publikasies van G.S. Nienaber die lig gesien, waarin die Saamwerk-Unie as taal- en kultuurbeweging beskryf is (Nienaber, 1931:130-149; Nienaber, 1933:167-194). Naas die werke van Nienaber is bronne oor die vestiging van Afrikaans as skryftaal ook deur G. Besselaar se publikasies verstewig (Besselaar, 1938:116, 117; Besselaar, 1941:46-64).

$\mathrm{Na}$ verloop van 32 jaar sedert Besselaar se publikasies, is die taaleksamenstelsel deur J.R. Olivier vanuit die Suid-Afrikaanse Taalbond se oogpunt beskryf (Olivier, 1973:1). Mnr. J.V. Smit het gedurende 1975 die prestasies van die Saamwerk-Unie in 'n reeks radiopraatjies behandel (INEG, lêer 3/1/2/1, 1975-08-10). B. Booyens het ook in 'n mindere mate aandag aan die Saamwerk-Unie in sy werk gegee (Booyens, 1983:66). Gedurende 1987 het J.C. Steyn die taalstryd in nasionale konteks beskryf en die milieu geskets waarin die Afrikaanse taaleksamens ontwikkel het (Steyn, 1987:1, 20, 30, 46, 68).

Die werksaamhede van die Saamwerk-Unie vorm ook 'n subtema van 'n proefskrif wat in 1987 oor adv. Jansen voltooi is (Prinsloo, 1987:242248). Die dokumente van die Saamwerk-Unie bied insgelyks 'n baie breedvoerige beeld oor die taaleksamenkwessie (INEG, lêers $1 / 2 / 2 / 2 / 4$, 3/1/2/1, 2/7/1/1/1, 1/3/2/1/1,2/8/1/1/1).

Dit is opvallend dat die Natalse taaleksamens nie in die algemene werke wat oor die stryd om die vestiging van Afrikaans handel, aan die orde gestel is nie (Pienaar, 1946:329-385; Zietsman, 1992:111-195).

Die beslaggewing van Afrikaanse taaleksamens in Natal word teen die agtergrond van die bovermelde literatuur soos volg aangebied. In die eerste plek word die stigting van die Saamwerk-Unie teen die breër agtergrond van die kulturele beweging in Natalse Afrikanergeledere geskets. Tweedens word die ontwikkeling van die Saamwerk-Unie se taaleksamens aangetoon. Die taalpolemiek wat vir 'n tyd tussen die Taalbond en die Saamwerk-Unie geheers het, word ook toegelig. Die artikel word deur ' $n$ waardebepaling oor hierdie ontwikkeling afgesluit. 


\section{Die kultuurmilieu in Suid-Afrika en die stigting van die Saamwerk-Unie}

In hierdie onderafdeling sal spesifiek gelet word op die Suid-Afrikaanse kultuurmilieu, die invloed daarvan op die geledere van die Natalse Afrikaner en die rol wat dit gespeel het in die stigting van die SaamwerkUnie.

Die Suid-Afrikaanse Taalbond is in 1890 gestig met die hoofdoel om die regte van die Afrikanervolkstaal (bedoelende Hollands) te bevorder. Sedert 1892 is Hollandse taalontwikkelingseksamens deur takke van die Taalbond geskryf. Teen 1899 het die jaarlikse inskrywings so gestyg dat 1205 kandidate in die vyf Taalbondeksamens geslaag het. Die eksamens was die Laer, Hoër en Hoogste Hollandse Taaleksamens en die Laer en Hoër Geskiedeniseksamens. Die Tweede Vryheidsoorlog het veroorsaak dat die Taalbondeksamens doodgeloop het. $\mathrm{Na}$ die heroprigting van die Taalbond in 1903 het die liggaam 'n tweede ontwikkelingsfase beleef, naamlik om gelyke taalregte vir die Afrikaner te verkry. Die Taalbond het vanaf 19101925 in 'n administratiewe eksamenliggaam ontwikkel (Olivier, 1973:1, $11,12,15,25-27)$.

Intussen het 'n klein groepie Afrikaners sedert 1906 die leiding in die Pietermaritzburgse Afrikaanssprekende gemeenskap geneem (Nienabër, 1931:124; De Afrikaner, 1905-12-07). Hul visie het om een doel gewentel, naamlik om die selfbewussyn van die provinsie se Afrikaners te ontwikkel. Die ontwikkelingsproses was gerig op die benutting van die Afrikaners se kultuurgoedere, sodat die Afrikaner 'n gelykwaardige staanplek teenoor die diepgewortelde Britse tradisie in Natal kon inneem (Besselaar, 1941:53).

Die oorheersende posisie van Engels teenoor Nederlands/Afrikaans in Natal het persone in talle Afrikaanse organisasies genoop om, voor en na Uniewording, onverpoos vir die erkenning van hul taal te stry. Die persone was deelgenote van 'n kulturele ontwaking wat na 1902 landswyd in Afrikanergeledere posgevat het - 'n ontwaking wat in hoofsaak deur Milnerisme en die doelbewuste verengelsingsbeleid geïnspireer is. Die kulturele oplewing is gelei deur 'n massa-aksie van Afrikanerkultuurleiers, politici, skrywers, joernaliste en digters, wat hul toevlug tot die taal, geskiedenis en godsdiens geneem het (Steyn, 1987:30-51). 
Hierdie merkwaardige kulturele ontwaking in die geledere van Afrikaners is onder meer deur taalbevorderingsaksies op taalgebruikersvlak gekenmerk. Dit het meestal om gesellige byeenkomste en werksaamhede van verenigings en organisasies soos debatsverenigings, Christelike jongeliedeverenigings, toneelgeselskappe, die Suid-Afrikaanse Akademie en Waaksaamheidskomitees, die Organisasie van Hollandse en Afrikaanse Taalvriende en die Saamwerk-Unie gewentel. Die bedrywighede het die Natalse Afrikaner op taal- en kultuurgebied saamgesnoer (Nienaber, 1933:121). Bun Booyens het die verenigings daarom as die sosiale, kulturele en intellektuele sentra van die Afrikaner bestempel (Booyens, 1983:12).

Die ontwikkelingsproses op taal- en kultuurgebied het onder andere uiting gevind in 'n aktiewe veldtog deur die voorstanders van Afrikaans, om Afrikaans nie slegs as spreektaal nie, maar ook as skryftaal te vestig (Booyens, 1983:67).

\section{Die stigting van die Saamwerk-Unie van Natalse Vereniginge, 1917}

Vanaf 1909-1916 het daar byna jaarliks 'n koor van stemme opgegaan om die ongeveer 11 tot 15 aktiewe Natalse debats- en jongeliedeverenigings in 'n unie saam te snoer (De Afrikaner, 1909-02-25).

Op 24 en 25 Mei 1917 het 'n kongres in die Gedenksaal in Pietermaritzburg plaasgevind ten einde die kwessie van 'n debatsunie uit te pluis. Tydens die kongres het nagenoeg 48 afgevaardigdes van 17 verenigings, op grond van 23 besprekingspunte en 'n voorlopige konstitusie, besluit om 'n debatsunie genaamd die "Saamwerk-Unie van Natalse Vereniginge" te stig (INEG, lêer 305, 1917-06-15; De Afrikaner, 1917-05-25).

Die besprekingspunt oor die amptelike taal van die debatsunie het byvoorbeeld vurige debatte opgelewer. Mnr. J.J. Boshoff, van die Middle Rest Jongeliede Debatsvereniging, was een van die persone wat geesdriftig vir Afrikaans gepleit het. Ander sprekers het weer die gebruik van Nederlands verdedig (INEG, lêer 1/4/2/1/1, 1917-05-24, 25). Die kongresgangers het uiteindelik besluit dat Afrikaans die Saamwerk-Unie se amptelike taal sou wees (INEG, lêer 305, 1917-06-15). 
In 'n daaropvolgende beskrywingspunt het die Pietermaritzburgse Debatsen Letterkundige Vereniging versoek dat boeke voorgeskryf moes word waaroor eksamens afgelê kon word volgens die grondslag van die Vrystaatse naskoolse opvoedkundige stelsel en die Chautauqua Lees- en Studiesirkel. Die beskrywingspunt het ook die aflê van Afrikaanse taaleksamens in die vooruitsig gestel (De Afrikaner, 1917-05-11). In 'n lewendige debat het verskeie kongresgangers hierdie voorstelle ondersteun, maar tog besware gehad teen die naam Chautauqua en die voorstel om by 'n Vrystaatse beweging in te skakel.

Eerw. J.J. Ross, die stigter van die Chautauqua-beweging te Kestell, het ter inligting van die afgevaardigdes die opvoedkundige rol van die debatsverenigings uiteengesit. Dié rol was om op 'n informele wyse aan die volk kennis te gee wat hulle veral op die platteland ontbreek het kennis wat deur die aankweek van leeslus en die verspreiding van boeke bereik kon word. Ross het verduidelik hoe hy in Amerika met die Chautauqua-beweging by naskoolse opvoedkundige sentra kennis gemaak het en hoe hy dit in 'n gewysigde en aangepaste vorm sedert 1904 op Kestell gebruik het (De Afrikaner, 1917-05-29).

Die referaat het heelwat vrae uitgelok en 'n lewendige debat tot gevolg gehad (INEG, leer 305, 1917-06-15). Daar is eindelik besluit "dat dit aan die bestuur opgedra word om boeke voor te skryf vir bestudering deur lede van vereniginge wat dit begeer, en eksamens daarop af te neem" (INEG, lêer 305, 1917-06-15). Die besluit was in ooreenstemming met die Hollandse taaleksamens wat reeds sedert 1892 deur takke van die SuidAfrikaanse Taalbond behartig is (Olivier, 1973:1, 11, 12, 15).

Die kongresgangers het 'n hoofbestuur verkies met die volgende Pietermaritzburgers daarop verteenwoordig: adv. E.G. Jansen (voorsitter), ds. G.M. Pellissier (ondervoorsitter) en dr. G. Besselaar (sekretaris). Hiermee het die kongresgangers vir die klein groepie Pietermaritzburgers oplaas 'n groen lig gegee, min wetende dat hierdie persone die bogenoemde besluit, naamlik om boeke vir bestudering voor te skryf, in 'n unieke eksamenstelsel sou ontwikkel (INEG, leer 305, 1917-06-15).

Hiermee het die Natalse Afrikaners 'n kultuureksperiment van stapel gestuur. Vir die eerste keer sedert 1910 was die Natalse Afrikaanssprekendes wat by hierdie tipe kultuurbewegings betrokke was, saam- 
gesnoer in 'n oënskynlik lewenskragtige nuwe debatsunie met duidelike doelwitte.

\section{Die ontwikkeling van 'n Afrikaanse taaleksamen- stelsel vir Natal}

Die Saamwerk-Unie se hoofbestuur was vasbeslote om 'n sukses te maak van die stigtingskongres se besluit om die taaleksamenstelsel in te stel. Tydens die hoofbestuur se eerste vergadering op 19 Julie 1917 is besluit om twee afsonderlike eksamenstelsels te ontwikkel.

Die een stelsel, die Studiesirkeleksamen wat daarop gemik was om kandidate se algemene kennis te verbeter, was op die lees van die Vrystaatse Chautauqua-beweging gebaseer. Die eerste eksamen in dié reeks het in Maart 1918 plaasgevind en het oor die inhoud van vyf voorgeskrewe boeke gehandel. Die eksamengeld het $2 / 6$ beloop. Vir hierdie doel is die hoofbestuurspan as 'n Eksamenkommissie benoem (INEG, lêer 1/4/2/1/1, 1917-07-19; De Afrikaner, 1917-09-07). Die aflê van die Studiesirkeleksamen is na 'n jaar weens swak belangstelling gestaak (De Afrikaner, 1918-05-28).

Die ander stelsel was die omstrede maar tog byderwetse voorstel om die eerste Afrikaanse taaleksamens in Suid-Afrika in te stel. Die hoofbestuur het groot planne vir hierdie taaleksamens gehad. Hulle het pas na die verskyning van die Suid-Afrikaanse Akademie se Afrikaanse woordelvs en spelreëls (Suid-Afrikaanse Akademie vir Wetenskap en Kuns, 1917:1196) besluit om 500 of 1000 kopieë vir die beoogde taaleksamens te bekom (De Afrikaner, 1917-10-12). Mev. Mabel Jansen, 'n onderwyseres wat oor 'n B.A.-graad beskik het (Jacobs, 1981:1, 34), het opdrag ontvang om die eksamenstelsel te beplan (Nienaber, 1933:177; NAB, lêer 4, 194205-31).

Hierdie taaleksamen het uit drie afdelings bestaan. Dit het die kandidate se taalvermoë in opeenvolgende vlakke van gevorderdheid getoets, en het as die Laer, Hoër en Hoogste Afrikaanse Taaleksamen bekendgestaan (De Afrikaner, 1917-09-07).

Die doel van die taaleksamens was om kandidate met hul Afrikaanse taalontwikkeling te help, veral omdat dit vir die ontwikkeling van persone 
op die platteland van groot waarde kon wees (NAB, lêer 4, 1942-05-31; De Afrikaner, 1918-05-28).

Die eerste Laer Afrikaanse Taaleksamen is op 3 Augustus 1917 in die pers bekendgestel. Dié taaleksamens het onder die ywerige hand van mev. Jansen ver buite die grense van Natal weerklank gevind (De Afrikaner, 1917-08-10). Nadat dagblaaie in ander provinsies die Natalse taaleksamenstelsel aangekondig het, is heelwat briewe van belangstellendes buite Natal ontvang (De Afrikaner, 1917-10-19).

Ten einde voornemende kandidate behulpsaam te wees het mev. Jansen, as korresponderende sekretaresse van die hoofbestuur, gereeld taalwenke gepubliseer in die Saamwerk-Unie se rubriek wat in De Afrikaner verskyn het. Enige persoon kon vir hierdie eksamen ingeskryf het. Aan elke kandidaat is grammatikareëls en 'n vraestel gestuur wat hulle gedurende Desember 1917 tuis moes voltooi (De Afrikaner, 1918-05-28).

Die vraestel vir die Laer Afrikaanse Taaleksamen het byvoorbeeld uit tien vrae bestaan. Sewe vrae het oor die Afrikaanse woordelys en spelreëls gehandel. Die res van die vraestel het 'n vertaling uit Hollands na Afrikaans, 'n sakebrief en 'n opstel ingesluit (De Afrikaner, 1917-09-07). Die kandidate moes die vraestelle binne 'n week sonder enige toesig voltooi en kon enige boek oor Afrikaanse spelreëls as bron geraadpleeg het. Die doel van die eksamen was immers nie 'n geheuetoets nie, maar om die kandidaat se taalvaardigheid te bepaal en te bevorder (Jacobs, 1981:36).

Daar het 406 kandidate vir die eerste Laer Afrikaanse Taaleksamen ingeskryf, waarvan slegs 65 persone uit Natal afkomstig was. Die groot getal inskrywings het vir die bestuur daarop gedui dat hulle 'n behoefte by Afrikaners geïdentifiseer het (De Afrikaner, 1917-09-07, 1918-05-28). Die taaleksamen het egter 'n verlies van $£ 2.11 .3$ getoon, wat daarop gedui het dat die inskrywingsgeld van een sjieling te min was om alle uitgawes te dek.

Die bestuur het ook pryse vir die beste kandidate, sowel as sertifikate vir alle suksesvolle kandidate uitgereik (De Afrikaner, 1918-03-15, 1918-0528). Adv. C.R. Swart, die latere staatspresident, het byvoorbeeld $85 \%$ vir die eksamen behaal (Jacobs, 1981:35). Die Natalse Christelike Vrouevereniging (NCVV) het goedgunstiglik ingewillig om een goue en vier silwer medaljes vir die beste kandidate te borg. Aangesien hierdie pryse 
deur persone buite Natal gewen is, het die bestuur besluit om boekpryse aan die tien beste kandidate uit Natal toe te ken. Die plan het die bestuur 'n verdere $£ 10$ uit die sak gejaag wat tydens die tweede SaamwerkUniekongres deur ' $n$ kollekte met $\mathcal{L} 7$ aangevul is (De Afrikaner, 1918-0528).

Gedurende 1918 is bogenoemde taalwenke wat oor verskeie grammatikale aspekte soos werkwoorde, klanke en vormleer gehandel het, in boekvorm oorgedruk en beskikbaar gestel. Hierdie boekie is later deur mev. Jansen en mnr. C.M. Booysen bygewerk, wat tot die publikasie van die Praktiese grammatika van die Afrikaanse taal (Jansen, 1921:1-163) gelei het (Jacobs, 1981:33).

Lede van die Saamwerk-Unie was tydens die 1918-kongres te Vryheid met reg trots op die gunstige ontvangs van die Laer Afrikaanse Taaleksamen. Adv. Jansen het sy spyt uitgespreek oor die trae belangstelling wat lede in die Studiesirkeleksamen getoon het, terwyl die getal inskrywings vir die Laer Afrikaanse Taaleksamen hom verbaas het (De Afrikaner, 1918-0528). Hy het ook die eerste sertifikate aan kandidate uitgereik - 'n gebeurtenis waaroor soos volg berig is: "Onvergeetlik was die moment toe mnr. J.J. Grové, 'n grysaard uit die distrik Dundee, onder groot gejuig na die verhoog kom om ook sy sertifikaat te ontvang" (Jansen, 1941:15; De Afrikaner, 1918-05-31).

Die sluitingsdatum vir die tweede Laer en eerste Hoër Taaleksamen is op 31 Augustus 1918 vasgestel (De Afrikaner, 1918-07-26), maar as gevolg van die groot griepepidemie is die nasien van die vraestelle vertraag (De Afrikaner, 1919-01-03, 1919-02-07). Die eksaminatore het verklaar dat die kandidate uitstekende werk gelewer het en het die hoop uitgespreek dat die toenemende gebruik van Afrikaans tot groter eenvormigheid sou lei. Hulle het die publiek daarop gewys dat Afrikaans net soveel studie as ander tale verg (De Afrikaner, 1919-02-07).

Die bekendstelling van die tweede taaleksamen is deur De Volkstem veroordeel, omdat die Saamwerk-Unie nie die saak oorgelaat het aan 'n liggaam met 'n hoër wetenskaplike prestigewaarde nie. Besselaar en Jansen het hierdie kritiek in De Afrikaner beantwoord en verklaar dat hulle reeds die Suid-Afrikaanse Akademie vir Wetenskap en Kuns in hierdie verband genader het. Die Saamwerk-Unie was vasberade om met hierdie 
eksamens voort te gaan tot tyd en wyl die Akademie 'n besluit oor die aangeleentheid geneem het (De Afrikaner, 1919-01-28). Die SaamwerkUnie het gevolglik op 4 April 1919 die derde taaleksamenprogram aangekondig (De Afrikaner, 1919-04-04).

Jansen het in sy voorsittersrede by die 1920-Saamwerk-Uniekongres te Winterton verklaar dat die beweging as gevolg van sy taaleksamens landwye bekendheid verwerf het. Die sukses wat die Saamwerk-Unie se Afrikaanse taaleksamens die vorige drie jaar behaal het, het volgens Jansen tot die Akademie se besluit gelei om die Taalbondeksamens ook in Afrikaans af te neem. 'n Verdere bewys van die bekendheid wat die Saamwerk-Unie in 'n kort tydperk verwerf het, was volgens Jansen die feit dat die Unie se werksaamhede in E.C. Pienaar se werk oor Taal en poësie van die Tweede Afrikaanse Taalbeweging vermeld is (Pienaar, 1919:1-302; vgl. Pienaar, 1931:51-135). Die bovermelde maatreëls van die SuidAfrikaanse Akademie het tot gevolg gehad dat die kongres besluit het om die voortsetting of beëindiging van die taaleksamens aan die hoofbestuur oor te laat (Die Afrikaner, 1920-05-21).

Die inskrywingsgeld vir die Saamwerk-Unie se 1920-taaleksamens het 1/vir die Laer, 1/6 vir die Hoër en 2/- vir die Hoogste Taaleksamen beloop en het eweneens inskrywings oor die hele land gelok (Die Afrikaner, 192103-01, 1921-03-04). Volgens Jansen het hierdie eksamenstelsel Afrikaans flink bevorder (Die Afrikaner, 1921-05-17). Ten tye van die Paulpietersburgse kongres in 1921 is vermeld dat 250 sertifikate na afloop van die eksamen uitgereik is. $\mathrm{Na}$ verloop van vier jaar was daar reeds 1340 sertifikate uitgereik.

Mev. Jansen en haar broer, ds. Pellissier, het as die eksaminatore vir die 1920-taaleksamen se Laer Afdeling opgetree. Die Hoër Afdeling is deur mev. Jansen en mnr. Booysen, en die Hoogste Afdeling deur prof. J.J. Smith en dr. T.H. le Roux geëksamineer. Die eksaminatore het ook vermeld dat die kandidate se werk in die 1920-eksamen aansienlik verbeter het. Die NCVV het weer medaljes aan die beste presteerder in elke afdeling toegeken. Hierdie drie medaljes, een in elke afdeling, is weer eens aan kandidate uit die ander provinsies toegeken.

Tydens die 1920-kongres het die hoofbestuur met trots gerapporteer dat die waarde van die taaleksamensertifikate nie geringgeskat moes word nie. 
Die rede hiervoor was die toenemende navraag wat die bestuur uit alle dele van die land ontvang het, en die feit dat selfs onderwysdepartemente belangstelling in hierdie eksamens getoon het (Die Afrikaner, 1921-05-20).

Die Afrikaanse taaleksamen van 1921 is op Saterdag 22 Oktober afgeneem (Die Afrikaner, 1921-07-01). Die eksaminatore vir die drie afdelings van die eksamens was dieselfde persone as die vorige jaar, behalwe dat dr. H. Viljoen prof. Smith vervang het. 'n Getal van 772 kandidate het vir die drie afdelings ingeskryf, waarvan 578 geslaag het. Natal het gedurende hierdie eksamen slegs 55 kandidate opgelewer (Die Afrikaner, 1922-06-16). Volgens mev. Jansen was die standaard van die Hoër Afdeling, wat sy en prof. Besselaar nagesien het, die hoogste sedert die taaleksamens ingestel is (Die Afrikaner, 1922-01-27, 1922-02-17).

'n Rekordgetal van 918 inskrywings is vir die 1922-taaleksamens ontvang en 628 sertifikate is uitgereik. Die omvang van die inskrywings het die hoofbestuur genoop om die administrasie van die eksamens aan die Nasionale Pers oor te dra (Die Afrikaner, 1923-06-08).

Tydens 'n hoofbestuursvergadering van 8 Augustus 1922 is adv. en mev. Jansen en proff. Besselaar, Viljoen en Booysen as die Eksamenkommissielede vir die volgende eksamen aangestel (Die Afrikaner, 192208-18). Die program vir hierdie 1923-taaleksamens is op 20 Maart 1923 aangekondig (Die Afrikaner, 1923-03-20). Tydens die sewende Saamwerk-Uniekongres in Mei 1923 was adv. Jansen van mening dat hierdie taaleksamens moontlik 'n plekkie in die geskiedenis van die Afrikaanse taalstryd kon verkry. Hy het ook sy blydskap uitgespreek oor die groter getal Natallers wat vir hierdie taaleksamens ingeskryf het (Die Afrikaner, 1923-05-11).

Ten tye van die agste jaarkongres van die Saamwerk-Unie gedurende Mei 1924 het prof. Besselaar bekendgemaak dat die Afrikaanse taaleksamenstelsel wat sedert 1917 deur die Saamwerk-Unie behartig is, gewysig moes word. Die rede hiervoor was dat daar reeds samewerkingsonderhandelings met die Suid-Afrikaanse Akademie en die Taalbond aangeknoop is. Die eksamenstelsel het so 'n groot omvang gehad dat die Saamwerk-Unie, volgens Besselaar, huiwerig was om alleen daarmee voort te gaan.

Besselaar het dit as ' $n$ besondere eer beskou dat die Saamwerk-Unie die eerste uitsluitlik Afrikaanse taaleksamens ingestel het. Hy het die kongres Literator 16 (2) Aug. 1995:225-245

ISSN 0258-2279 
versoek om die saak aan die hoofbestuur oor te laat, sodat hierdie gevestigde en suksesvolle eksamenstelsel mettertyd in samehang met die Taalbond verder kon ontwikkel (Die Afrikaner, 1924-07-18).

Tabel no. 1 toon dat die getal kandidate wat vir die taaleksamens gedurende die tydperk 1917-1928 ingeskryf het, jaar na jaar gestyg het (Nienaber, 1933:181). Hierdie tabel toon die groot getal persone wat deur hierdie eksamenstelsel hul taalvaardigheid verbeter het, en dui ook daarop dat die Laer Taaleksamen die gewildste was. Die gemiddelde slaagsyfer van nagenoeg $70 \%$ toon dat die eksaminatore uit die staanspoor gepoog het om 'n sekere standaard vir die informele taaleksamens te vestig. Dit is ook moontlik dat die lae geletterdheidspeil van kandidate en die hoë standaard wat gehandhaaf is, kandidate afgeskrik het om vir die Hoogste Taaleksamen in te skryf. Die gewildheid van hierdie taaleksamenstelsel het egter jaar na jaar toegeneem. Teen 1974 is byvoorbeeld 'n getal van 19729 eksameninskrywings per jaar deur die Saamwerk-Unie gehanteer (INEG, lêer $4 / 1 / 1 / 1$, s.j.).

\section{Die stryd om die Saamwerk-Unie se taaleksamen- stelsel te erken}

Die toenemende getal inskrywings het die hoofbestuur van die SaamwerkUnie se vertroue versterk om weer eens met die Suid-Afrikaanse Akademie te onderhandel om die Afrikaanse taaleksamens op 'n permanente en amptelike grondslag te vestig (INEG, lêer 304, 1920-05-13; Die Afrikaner, 1920-05-21).

Terwyl die hoofbestuur gedroom het "van die dag dat onse eksamen op gelijke voet met die taalbond sal staan, wanneer die hele Suid-Afrika sal ijwer en streef om daarin deel te neem, en wanneer die onderwijs departement self onse eksamen sal erken" (De Afrikaner, 1917-08-10), is hierdie poging deur ander taalstryders buite Natal verkleineer as 'n voorbarige daad van 'n junta in Pietermaritzburg (Jansen, 1941:15; NAB, lêer 4, 1942-05-31; De Afrikaner, 1919-01-28).

Die taaleksamens wat gedurende die onderhawige tydperk deur die SuidAfrikaanse Akademie erken is, is deur die Taalbond in vereenvoudigde Hollands afgeneem (Olivier, 1973:12-15). Volgens Jansen was die Taal- 
bond se taaleksamens nie op die Afrikaner se eietydse taalvaardigheidsbehoeftes ingestel nie. In Natal was die bevordering van Afrikaans in plaas van vereenvoudigde Hollands vir Jansen prakties gefundeer omdat dit die eietydse taalvaardigheidsbehoeftes van die taalgebruikers op grondvlak geakkommodeer het (INEG, lêer 304, 1920-05-13; Die Afrikaner, 1920-05-21).

\section{Tabel no. 1: Die getal kandidate wat gedurende 1917- 1928 vir die Saamwerk-Unie se Afrikaanse taaleksamens ingeskryf en geslaag het}

\begin{tabular}{|c|c|c|c|c|c|c|}
\hline \multirow{2}{*}{ Jaar } & \multicolumn{2}{|c|}{ Laer } & \multicolumn{2}{c|}{ Hoër } & \multicolumn{2}{c|}{ Hoogste } \\
\hline & Ingesk. & Gesl. & Ingesk. & Gesl. & Ingesk. & Gesl. \\
\hline 1917 & 406 & 316 & - & - & - & - \\
\hline 1918 & 265 & 230 & 195 & 138 & - & - \\
\hline 1920 & 285 & 194 & 61 & 43 & 31 & 13 \\
\hline 1921 & 519 & 419 & 192 & 127 & 61 & 32 \\
\hline 1922 & 740 & 521 & 137 & 88 & 41 & 19 \\
\hline 1923 & 737 & 506 & 335 & 250 & 15 & 8 \\
\hline 1924 & 1210 & 916 & 397 & 289 & 19 & - \\
\hline 1925 & 1414 & 1218 & 441 & 321 & 13 & - \\
\hline 1926 & 1945 & 1360 & 876 & 738 & - & 22 \\
\hline 1927 & 2979 & - & 1260 & - & 204 & - \\
\hline 1928 & 3118 & - & 1309 & - & 124 & - \\
\hline
\end{tabular}

Ingesk $=$ ingeskryf $\quad$ Gesl. $=$ geslaag $\quad-=$ inligting onbekend

Die bevordering van Afrikaans het vir die Saamwerk-Unie ontwikkel in 'n stryd om die erkenning van hul taaleksamens. Die poging om die Taalbond en die Saamwerk-Unie se eksamenstelsels aan mekaar te koppel of wedersyds erken te kry, het vir bykans 11 jaar voortgesleep (Nienaber, 1933:182-184; Olivier, 1973:57-62). 
Die geskil tussen die Saamwerk-Unie en die Taalbond het eerstens gewentel om die brandende taalkeusepolemiek tussen Hollands of Afrikaans as 'volkstaal' vir die Afrikaner.

Hoewel die Taalbond tydens die Akademie se stigting nie amptelik verteenwoordig was nie, het Taalbondhoofbestuurslede in die Breë Komitee van die Akademie gedien. Die Taalbond met sy sterk Hollandse inslag was nie geesdriftig oor die Akademie se stigting nie. Hulle was blykbaar bevrees dat voorstanders van Afrikaans hierdie organisasie sou oorheers. Ten spyte van die aanvanklike huiwering het die Taalbond en die Akademie tog in 1912 'n ooreenkoms aangegaan. Hiervolgens sou die Taalbond as die Akademie se Eksamenkommissie optree om die Hollandse taal te bevorder (Olivier, 1973:29, 30, 49, 50).

Kragtens bogenoemde ooreenkoms het die Taalbondeksamens as Hollandse taaleksamens sedert 1913 landswyd inslag gevind. Hierteenoor het die Natallers, met hul verklaarde beleid om Afrikaans te bevorder en eksamens in Afrikaans af te neem, sedert 1917 as 'n gedugte konkurrent vir die Taalbond se taaleksamens na vore getree (Olivier, 1973:51). Die Taalbond was dus die vergestalting van die geleerde Hollandse invloed (Olivier, 1973:17), terwyl die Saamwerk-Unie met sy populêre aanslag Afrikaans op grondvlak voorgestaan en bevorder het. Die Saamwerk-Unie het veral gepoog om Afrikaans te bevorder in die geledere van die ongeletterde moedertaalsprekers.

In die tweede plek het die voortbestaan van die Saamwerk-Unie se ongekontroleerde tuiseksamens naas die amptelik erkende prestigeeksamens van die Taalbond, moeilik beantwoordbare kwelvrae oor die status van die Afrikaanse taaleksamens uitgelok (De Afrikaner, 1919-0128). Hierdie omstandighede het veroorsaak dat adv. Jansen in 'n toenaderingsaksie ten einde die Natalse Afrikaanse taaleksamens in akademiekringe erken te kry die wind van voor gekry het.

Op die tweede Saamwerk-Uniekongres te Vryheid gedurende 22-24 Mei 1918, is besluit om met die Akademie te affilieer (De Afrikaner, 1918-0607). As geaffilieerde liggaam het hulle die Akademie versoek om die Afrikaanse taaleksamens oor te neem, sodat die eksamenstelsel aan dié organisasie met hoë wetenskaplike prestigewaarde oorgelaat kon word. Tydens die Akademiesitting van Julie 1918 het Jansen die Saamwerk- 
Unie-eksamens verduidelik, waarna die wenslikheid van Afrikaanse taaleksamens bevestig is.

Die Akademie het gevolglik sy Eksamenkommissie (die Taalbond) versoek om die kwessie van Afrikaanse taaleksamens gunstig te oorweeg en met die Saamwerk-Unie in verbinding te tree (De Afrikaner, 1919-01-28; Olivier, 1973:57). Jansen het in Desember 1919 die Akademie se besluit oor die Afrikaanse taaleksamens en die Taalbond se onwillige houding om met die Saamwerk-Unie te onderhandel gekritiseer. Dr. W.M.R. Malherbe het verduidelik dat die hantering van die taaleksamens in die Taalbond se hande is. Hierteenoor was Malherbe van mening dat die Akademieraad die Saamwerk-Unie moes versoek om die hele stelsel van taaleksamens aan die Taalbond oor te laat (INEG, lêer 303, 1920-02-12).

Die Taalbond het egter reeds in September 1919 besluit om in 1920 ook eksamens in Afrikaans af te neem (Olivier, 1973:35-37). Malherbe het namens die Akademie die hoop uitgespreek dat die Saamwerk-Unie op grond van hierdie besluit die taaleksamenstelsel aan die Taalbond sou oorlaat (INEG, lêer 303, 1921-04-21).

Tydens die Saamwerk-Uniekongres in Mei 1920 te Winterton het Jansen gesê dat ongeveer 100 briewe ontvang is, waarin inligting oor die taaleksamens vir 1920 gevra het. Dit het die bestuur laat besluit om nog vir 1920 'n eksamen uit te skryf en besluite oor die toekoms van die taaleksamen aan die 1920-kongres oor te laat. Jansen het dit ook duidelik gestel dat die Akademie en die Taalbond van die Saamwerk-Unie verwag dat hierdie saak in die hande van die Taalbond gelaat moes word (INEG, lêer 304, 1920-05-13; Die Afrikaner, 1920-05-21). Die 1920-kongres het egter in beginsel besluit om hul taaleksamen voort te sit (Die SaamwerkUnie-Orgaan, 1920-05-28; INEG, lêer 303, 1923-09-10).

Die besluit het uiteindelik die twee kultuurliggame na 'n konferensietafel gedwing. Teen 1922 het die Saamwerk-Unie se Eksamenkommissie bestaan uit adv. en mev. Jansen, prof. Besselaar, dr. H. Viljoen en mnr. C.M. Booysen en het die kommissie steeds onafhanklik van die Taalbond gefunksioneer (Die Afrikaner, 1922-08-18; Nienaber, 1933:182, 183).

Die Taalbondsekretaris, ds. G.S. Malan, het gedurende 1924 sy hoofbestuur gewaarsku dat hul eksamens steeds deur 'n konkurrent uit Natal bedreig word. Die Taalbond se hoofbestuur het die saak onder die aandag 
van die Akademie gebring. Hulle het ook vir die eerste keer vir dr. G.G. Cillié, dr. E.C. Pienaar en ds. Malan as 'n kommissie benoem om die saak met die Saamwerk-Unie te bespreek sodat 'n bevredigende skikking getref kon word. Die twee liggame het na voorlopige onderhandelings besluit om 'n vergadering van verteenwoordigers van albei liggame te hou (Olivier, 1973:57).

Op 18 April 1925 het die Saamwerk-Unieverteenwoordigers en die Taalbondverteenwoordigers mekaar ontmoet. Hulle het 'n voorlopige samewerkingsooreenkoms opgestel wat deur die twee hoofbesture goedgekeur moes word. Hierdie ooreenkoms het die volgende sake ingesluit: 'n gesamentlike liggaam moes die taaleksamens beheer, die liggaam moes deur die Akademie erken word en sertifikate moes uitgereik word (Die Afrikaner, 1925-07-03). Nadat 'n paar haakplekke en verdere wysigings deur die twee hoofbesture aangebring is, is die 'ooreenkoms' op 26 Januarie 1926 in Kaapstad deur verteenwoordigers van albei organisasies gefinaliseer. Dit moes nog net deur die twee hoofbesture en die Akademie, as beherende liggaam, goedgekeur word.

Die finale ooreenkoms oor die Afrikaanse taaleksamens wat op 2 April 1926 tussen die Suid-Afrikaanse Taalbond en die Eksamenkommissie van die Saamwerk-Unie gesluit is, het die doelstellings van albei organisasies beliggaam. Hierin is die noodsaaklikheid vir die voortbestaan van die Afrikaanse taaleksamens ook bevestig. Die ooreenkoms het bepaal dat daar 'n Laer, Hoër, Hoogste en Diploma-Taaleksamen sou wees. Die beoogde Laer Taaleksamen sou uitsluitlik 'n Afrikaanse eksamen wees, wat deur die Eksamenkommissie van die Saamwerk-Unie behartig moes word. Hierdie eksamen het uit 'n leestoets, die verklaring van idiome of 'n voorgeskrewe werk gehandel.

Kragtens die voorgestelde ooreenkoms moes die Taalbond die toekomstige taaleksamens administreer. Die Hoër Taaleksamen het uit drie afdelings, naamlik $A, B$ en $C$ bestaan. Afdeling $A$ was verpligtend en het oor Afrikaanse taalkunde gehandel wat in Afrikaans beantwoord moes word. Kandidate het 'n keuse tussen afdeling $B$ en $C$ gehad aangesien dit oor die letterkunde gehandel het. Afdeling B het vrae oor Afrikaanse en Nederlandse letterkunde bevat. Die vrae oor Nederlandse letterkunde kon in Nederlands beantwoord word. Afdeling $\mathrm{C}$ het vrae oor Afrikaanse letter- 
kunde bevat wat in Afrikaans beantwoord moes word. Die Hoogste en die Diploma-Taaleksamens sou uit Afrikaanse en Nederlandse werke bestaan wat in Afrikaans of Nederlands beantwoord kon word.

Die ooreenkoms het ook bepaal dat die Taalbond en die Saamwerk-Unie as afsonderlike organisasies sou voortbestaan, maar dat hul eksamenwerksaamhede aan die Gesamentlike Eksamenkommissie (GEK) opgedra moes word. Elke liggaam moes drie lede vir die GEK benoem. Die GEK moes jaarliks die program, inskrywingsvorms, finansiële sake en sertifikate vir die taaleksamens hanteer.

Die finalisering van die ooreenkoms tussen die twee liggame kan as die stigtingsdag van die GEK van die Suid-Afrikaanse Taalbond en die Saamwerk-Unie van Natalse Vereniginge beskou word. Tydens die tiende jaarkongres het die lede van die Saamwerk-Unie hierdie amalgamasie met die Taalbond goedgekeur (Die Afrikaner, 1926-05-14).

Daar het optimisme oor hierdie ooreenkoms tussen die twee strydende kultuurliggame geheers. Uiteenlopende interpretasieverskille en die praktiese uitvoering van die GEK-ooreenkoms het egter baie probleme en haakplekke opgelewer (Olivier, 1973:59-62; Die Afrikaner, 1927-07-05). Lede van die Taalbond was van mening dat die GEK wederregtelik besluite geneem het (INEG, lêer 303, 1927-05-28, lêer 306, 1926-04-02).

Die onderlinge verskille tussen die twee kultuurliggame het tot gevolg gehad dat die Saamwerk-Unie se Eksamenkommissie besluit het om die administrasie van hul taaleksamens by die Natalse Pers oor te neem en 'n voltydse klerk vir die doel aan te stel (Die Afrikaner, 1927-07-05). Die Dagbestuur van die Taalbond het insgelyks nie al die besluite van die GEK-vergadering bekragtig nie (INEG, lêer 303, 1928-04-18; Olivier, 1973:61). Mnr. Booysen, die sekretaris van die Saamwerk-Unie se Eksamenkommissie, het ook besluite van die Taalbond se Dagbestuur sterk veroordeel (INEG, lêer 303, 1928-03-26, lêer 2/9/1/4/1, 1928).

Dit het beteken dat onderlinge meningsverskille weer eens die GEK se werksaamhede lamgelê het. Lede van die Taalbond en GEK het Jansen, as voorsitter van die GEK, versoek om die saak te beredder (INEG, lêer 303, 1928-04-18). Jansen se skikkingsvoorstel oor die geskilpunt het behels dat die legitimiteit van die GEK se besluite minstens tot hul volgende vergadering deur die twee kultuurliggame erken moes word. Hy was Literator 16 (2) Aug. 1995:225-245

ISSN 0258-2279 241 
daarvan oortuig dat die Taalbond gewillig sou wees om in te stem dat enige besluit van die GEK altyd bindend sou wees, tensy 'n konstituerende liggaam binne ' $n$ beperkte tyd skriftelik by die GEK beswaar gemaak het (INEG, lêer 303, 1928-04-26). Die verteenwoordigers van die SaamwerkUnie en die Taalbond het die skikkingsvoorstel aanvaar (INEG, leer 303, 1928-05-04, lêer 303, 1928-05-16, lêer 303, 1928-05-19).

Die jarelange stryd om botsende belange tussen die twee organisasies is bevredigend opgelos op die derde vergadering van die GEK in Julie 1928 te Kaapstad. Die vergadering het 'n besluit aanvaar wat deur die Saamwerk-Unie en die Taalbond bekragtig is. Kragtens die besluit het daar uiteindelik, onder beskerming van die Akademie, 'n bevredigende konstitusionele basis vir samewerking tussen die twee kultuurliggame tot stand gekom (Olivier, 1973:61, 62). Die samewerkingsooreenkoms het verseker dat die taaleksamens op 'n veel beter grondslag geadministreer kon word (INEG, lêer 1/2/2/2, 1937-10-01, lêer 1/2/2/2/4, 1948-05-6, 7).

\section{6. 'n Algemene waardebepaling en die betekenis van hierdie ontwikkelingsfase}

Die Saamwerk-Unie se taaleksamenstelsel is deur taalliefhebbers sonder hoë akademiese kwalifikasies in die lewe geroep. Dit was 'n stelsel wat om praktiese redes van stapel gestuur is om die taalvaardigheid van Afrikaanssprekendes, en so hul geletterdheidsvlak, te verhoog. Die intervensie van die Akademie, wat nie sonder konflik geskied het nie, het die eksamenstelsel verbeter en uiteindelik 'n groter prestigewaarde daaraan verleen.

Die instelling van die taaleksamenstelsel het gevolglik tot die vestiging van 'n nuwe kultuurpatroon op taalgebied gelei. Die rede hiervoor is dat die taaleksamens duisende mense se taalvaardigheid in Afrikaans verbeter het. Leiersfigure in die Saamwerk-Unie was daarom verheug dat ongeletterdes deur die oefening en die bestudering van 'n groot reeks onderwerpe 'n spreekvaardigheid en natuurlike welsprekendheid ontwikkel het.

Die sukses van hierdie stigtingsdoelwit van die Saamwerk-Unie het ook gelei tot die vestiging van 'n saamwerkgees, wat bevrugtend op elke gebied van die Natalse Afrikaner se kultuurlewe ingewerk het (INEG, leer 4/1/1/1, s.j., lêer 3/1/2/1, Aug. 1975). Die sukses van die stigtingsdoelwit 
het inderdaad meegehelp om die Saamwerk-Unie as daadkragtige taal- en kultuurbeweging in Natal se Afrikanergeledere te vestig. Die ontwikkeling het gevolglik die Natalse Afrikaner van sy geestelike erfenis bewus gemaak (Die Natalse Afrikaner, 1938-04-11).

In hierdie opsig is die gebruik van Afrikaans as skryftaal bevorder (Die Natalse Afrikaner, 1941-04-15). Die Saamwerk-Unie is daarom as 'n kragstasie in die Natalse kultuurlewe bestempel (Die Natalse Afrikaner, 1941-04-08). Op grond van die sukses wat met die taaleksamens behaal is, kon mnr. J.J. Boshoff, die voorsitter van die Saamwerk-Unie, ten tye van die organisasie se 17 de jaarlikse kongres die pleidooi vir die beginsel van moedertaalonderrig in Natal begin propageer (Die Volksblad, 193304-17).

Die sukses van hierdie ontwikkelingsfase het die voorstanders van Afrikaans aangemoedig om dit nie net as spreek- en skryftaal nie, maar ook as amptelike taal gevestig te kry.

\section{Bibliografie}

\subsection{Instituut vir Eietydse Geskiedenis (INEG), UOVS}

\subsubsection{E.G. Jansenversameling}

Lêer 303: Brief van G. Besselaar aan E.G. Jansen, 1928-05-04.

Lêer 303: Brief van C.M. Booysen aan die Sekretaris van die GEK, 192803-26.

Lêer 303: Brief van C.M. Booysen aan E.G. Jansen, 1927-05-28.

Lêer 303: Brief van C.M. Booysen aan E.G. Jansen, 1928-04-18.

Lêer 303: Brief van E.C. Pienaar aan E.G. Jansen, 1928-04-18.

Lêer 303: Brief van E.G. Jansen aan G. Besselaar, P.C. Schoonees \& F.D. Hugo, 1928-04-26.

Lêer 303: Brief van E.G. Jansen aan C.M. Booysen, 1928-04-26.

Lêer 303: Brief van E.G. Jansen aan G.S. Malan, 1923-09-10.

Lêer 303: Brief van E.G. Jansen aan E.C. Pienaar, 1928-04-26.

Lêer 303: Brief van W.M.R. Malherbe aan E.G. Jansen, 1920-02-12.

Lêer 303: Brief van W.M.R. Malherbe an E.G. Jansen, 1921-04-21.

Lêer 303: Brief van E.C. Pienaar aan E.G. Jansen, 1928-05-19.

Lêer 303: $\quad$ Brief van P.C. Schoonees aan E.G. Jansen, 1928-05-16.

Lêer 304: E.G. Jansen se voorsittersrede, Saamwerk-Uniekongres, 192005-13. 
Lêer 305: $\quad$ Notule van die kongressitting, 1917-06-15.

Lêer 306: Finale ooreenkoms tussen die Suid-Afrikaanse Taalbond en die Eksamenkommissie van die Saamwerk-Unie van Natalse Vereniginge, 1926-04-02.

\subsubsection{Saamwerk-Unieversameling}

Lêer 1/2/2/2: Notule van kongressitting, 1937-10-01.

Lêer 1/2/2/2/4: Notule van kongressitting, 1948-05-6,7.

Lêer 1/2/2/2/4: Verskeie dokumente wat betrekking het op die SaamwerkUnie.

Lêer 1/3/2/1/1: Verskeie dokumente wat betrekking het op die SaamwerkUnie.

Lêer 1/4/2/1/1: Notule van die hoofbestuursvergadering, 1917-07-19.

Lêer 1/4/2/1/1: Notule van die kongressitting, 1917-05-24, 25.

Lêer 2/7/1/1/1: Verskeie dokumente wat betrekking het op die SaamwerkUnie.

Lêer 2/8/1/1/1: Verskeie dokumente wat betrekking het op die SaamwerkUnie.

Lêer 2/9/1/4/1: Korrespondensie met die Taalbond, 1928.

Lêer 2/10/1/1/1: Notules van Taalfeeskomiteevergaderings, 1959-02-26, 195903-23.

Lêer 3/1/2/1: J.V. Smit: 'n Algemene waardebepaling van die SaamwerkUnie in Natal (Radiopraatjie), Aug. 1975.

Lêer 3/1/2/1: J.V. Smit: Die Saamwerk-Unie van Natalse kultuurvereniginge (Radiopraatjie), 1975-08-10.

Lêer 3/1/2/1: Verskeie dokumente wat betrekking het op die SaamwerkUnie.

Lêer 4/1/1/1: Die Afrikaanse Taaleksamens van die Saamwerk-Unie, s.j.

\subsection{Natalse Argiefbewaarplek (NAB), Pietermaritzburg}

\subsubsection{A.G. du Toitversameling}

Lêer 4: $\quad$ Toespraak van E.G. Jansen, Saamwerk-Uniekongres, $1942-$ 05-31.

\subsection{Ander bronne}

Adam, H. \& Moodley, K. 1993. South Africa: Revived Nationalism vs Non-

Racialism. South African International, 23(4):140-146, Apr.

De Afrikaner, 1905, 1909, 1917, 1918, 1919.

Die Afrikaner, 1920, 1921, 1922, 1923, 1924, 1925, 1926, 1927. 
P.J.J. Prinsloo

Besselaar, G. 1938. Herinneringe uit die kinderjare van die Saamwerk-Unie. Die Saamwerk-Eeufeesgedenkuitgawe, 136:116-118, Des.

Besselaar, G. 1941. Sestig jaar belewenis van Dietse kultuur. Pretoria : Van Schaik.

Booyens, B. 1983. "Ek heb Geseg!": die verhaal van ons Jongeliede- en Debatsverenigings. Kaapstad : Human \& Rousseau.

Jacobs, T. 1981. Martha Mabel Jansen, 1889 tot 1979: 'n Kultuuroorsig. Port Elizabeth : UPE. (M.A.-verhandeling.)

Jansen, M. 1921. Praktiese grammatika van die Afrikaanse taal: Spesiaal vir gebruik in Afrikaans-medium skole tot en met matriek. Pietermaritzburg : Nasionale Pers.

Jansen, E.G. 1941. Ontstaan van die Saamwerk-Unie. Die Huisgenoot, 25(994): 15, April 11.

Die Natalse Afrikaner, 1938, 1941.

Nienaber, G.S. 1931. Die Afrikaanse Beweging. Deel 1. Pretoria : Van Schaik.

Nienaber, G.S. 1933. Honderd jaar Hollands in Natal. Pretoria : De Bussy.

Olivier, J.R. 1973. Die Suid-Afrikaanse Taalbond. In: Universiteit van

Stellenbosch. Annale, 34(3), Reeks B. Stellenbosch : US. p. 1-62.

Pienaar, E.C. 1919. Taal en poësie van die Tweede Afrikaanse Taalbeweging. Pretoria : s.n.

Pienaar, E.C. 1931. Taal en poësie van die Tweede Afrikaanse Taalbeweging. Kaapstad : Nasionale Pers.

Pienaar, E.C. 1946. Die triomf van Afrikaans: Historiese oorsig van die wording, ontwikkeling, skriftelike gebruik en geleidelike erkenning van ons taal. Kaapstad : Nasionale Pers.

Prinsloo, P.J.J. 1987. E.G. Jansen se rol in helang van die Afrikaners in Natal. Potchefstroom : PU vir CHO. (D.Litt.-proefskrif.)

Die Saamwerk-Unie-Orgaan, 1920-05-28.

Steyn, J.C. 1987. Trouwe Afrikaners: Aspekte van Afrikaner-Nasionalisme en Suid-Afrikaanse taalpolitiek, 1875-1938. Kaapstad : Tafelberg.

Suid-Afrikaanse Akademie vir Wetenskap en Kuns. 1917. Afrikaanse woordelys en spelreëls, Iste uitg. Bloemfontein : Volksblad-Boekhandel.

Zietsman, P.H. 1992. Die taal is gans die volk: woelinge en dryfvere in die stryd om die Afrikaner se taal. Pretoria : Universiteit van Suid-Afrika. 